\title{
Soil erosion modeled with USLE, GIS, and remote sensing: a case study of Ikkour watershed in Middle Atlas (Morocco)
}

\author{
Aafaf El Jazouli ${ }^{1}$, Ahmed Barakat ${ }^{*}$, Abdessamad Ghafiri², Saida El Moutaki ${ }^{2}$, Abderrahim Ettaqy ${ }^{3}$ \\ and Rida Khellouk'
}

\begin{abstract}
The Ikkour watershed located in the Middle Atlas Mountain (Morocco) has been a subject of serious soil erosion problems. This study aimed to assess the soil erosion susceptibility in this mountainous watershed using Universal Soil Loss Equation (USLE) and spectral indices integrated with Geographic Information System (GIS) environment. The USLE model required the integration of thematic factors' maps which are rainfall aggressiveness, length and steepness of the slope, vegetation cover, soil erodibility, and erosion control practices. These factors were calculated using remote sensing data and GIS. The USLE-based assessment showed that the estimated total annual potential soil loss was about 70.66 ton ha $^{-1}$ year $^{-1}$. This soil loss is favored by the steep slopes and degraded vegetation cover. The spectral index method, offering a qualitative evaluation of water erosion, showed different degrees of soil degradation in the study watershed according to $\mathrm{Fl}, \mathrm{Bl}, \mathrm{Cl}$, and NDVI. The results of this study displayed an agreement between the USLE model and spectral index approach, and indicated that the predicted soil erosion rate can be due to the most rugged land topography and an increase in agricultural areas. Indeed, these results can further assist the decision makers in implementation of suitable conservation program to reduce soil erosion.
\end{abstract}

Keywords: Ikkour watershed, Soil erosion, USLE, Spectral indices, GIS

\section{Introduction}

Soil erosion is a naturally occurring process and it is a normal geological phenomenon associated with the hydrologic cycle. It is a gradual process which occurs when the impact of water detaches and removes soil particles causing the soil to deteriorate. Soil erosion in catchment areas and the subsequent deposition in rivers, lakes, and reservoirs are of great concern for two reasons. Firstly, the rich and fertile soil is eroded in the catchment areas. Secondly, there is a reduction in reservoir capacity as well as degradation of downstream water quality. Soil loss is the result of soil erosion. This, in turn, decreases soil fertility and reduces crop yield. Soil erosion can never be stopped completely, but it can be mitigated to

\footnotetext{
*Correspondence: a.barakat@usms.ma

${ }^{1}$ Georesources and Environment Laboratory, Faculty of Sciences and Techniques, Sultan My Slimane University, Béni-Mellal, Morocco Full list of author information is available at the end of the article
}

some extent. There is considerable potential for the use of GIS technology as an aid to soil erosion inventory with reference to soil erosion modeling and erosion hazard assessment.

In Morocco, water erosion is the main cause of degradation of the soil capital and the environment. It affects, with varied intensities, about $40 \%$ of land in Morocco (FAO 1990). Annual soil loss exceeds 20 ton ha ${ }^{-1}$ year $^{-1}$ in the Mountainous regions of northern Morocco and varies between 10 and 20 ton $\mathrm{ha}^{-1}$ year $^{-1}$ in the preRif regions and 5 and 10 ton ha ${ }^{-1}$ year $^{-1}$ in Middle and High Atlas regions (MAEF 2001). In addition to soil loss, water erosion degrades water quality and causes siltingup of hydraulic infrastructure (Ben-Ali 2000). This erosion will only accelerate if adequate precautions are not taken early enough to address this emergency. Indeed, some scientific research on the vulnerability to climate change in the Mediterranean Region including Morocco indicates a trend toward an increasing aridity which 
inevitably accelerates water erosion (De Ploey et al. 1991; Joftic et al. 1992). In this situation, quantification of soil loss and delineation of degraded areas is necessary for effective conservation planning (Yadav and Sidhu 2010).

In the last decade, many scientific works using remote sensing and geographic information systems (GIS) technologies have been carried out to characterize soil erosion in large areas (Haboudane et al. 2007; Rahman et al. 2009; Meusburger et al. 2010; Benzer 2010; Biswas 2012; Dabral et al. 2008; Pandey et al. 2007; Sheikh et al. 2011). These works proved that these techniques provided very good information about eroding areas, such as soil types, lithological units, and vegetation cover, with reasonable costs and accuracy. Integrated into GIS and remote sensing, several models for predictive evaluation on soil erosion by water have been reported in some literature (e.g., Wischmeier and Smith 1978; Lal 2001; Fullen 2003; Merritt et al. 2003). Universal Soil Loss Equation (USLE) is considered as the best model and is being used worldwide for the estimation of surface erosion (e.g., Zhang et al. 2008; Alexakis et al. 2013; Perović et al. 2013; Chatterjee et al. 2014; Kourgialas et al. 2016). Its revised version, RUSLE (Renard et al. 1997), became mostly used to provide estimates of soil loss (Demirci and Karaburun 2012; Kumar et al. 2014; Ganasri and Ramesh 2015; Napoli et al. 2016; Rawat et al. 2016). Other studies (Baumgardner et al. 1986; Yesou et al. 1993; Escadafal et al. 1994; Hill et al. 1994; Haboudane et al. 2002) have shown the interest of spectral indices based on soil reflectance, such as form index (FI), coloration index $(\mathrm{CI})$, brightness index $(\mathrm{BI})$, and normalized difference vegetation index (NDVI), for characterizing soil surface state, especially in arid and semi-arid lands.

Keeping in view of the above aspects, this study was conducted to evaluate soil erosion rates in the Ikkour watershed located in the high basin of the Oum Er Rbia River that suffers detrimental effects through human activities (Barakat et al. 2016). The selected watershed is highly vulnerable to erosion; it constitutes one of the main areas of Morocco, where the limestone series of the lower Liassic outcrop widely and show an accentuated landform. Also, the watershed is characterized by semi-arid to sub-humid climate marked by spatial and temporal rainfall variability. These natural factors associated with the occupation of the soils promoted its vulnerability to erosion. In this regard, it became necessary to quantify and map soil erosion in the Ikkour watershed. In this study, USLE and spectral index models combined with GIS techniques were used to estimate soil erosion in the Ikkour watershed and to evaluate the spatial distribution of the soil erosion-prone areas. The results obtained by the two models were compared in order to complement each other to identify and to produce the soil erosion susceptibility maps.

\section{Methods}

\section{Study area}

The Ikkour watershed is located in the southwestern part of the Moroccan, Middle Atlas Mountain (Fig. 1), at $32^{\circ} 32^{\prime}-32^{\circ} 40^{\prime} \mathrm{N}$ and $5^{\circ} 50^{\prime}-5^{\circ} 58^{\prime} \mathrm{W}$, and covered an area of $55 \mathrm{~km}^{2}$. It is characterized by a semi-arid climate with rains frequently grouped during a few days per month. Precipitations are characterized by irregular distribution, spread irregularly from October-November to April-May with predominance in December, and are almost non-existent in July and August. The mean annual rainfall in the Oum Er Rbia Basin is $666 \mathrm{~mm}$. The temperature varies between 5 and $50{ }^{\circ} \mathrm{C}$ with an average value of $17.7^{\circ} \mathrm{C}$. The geology of the region is dominated by the Jurassic formations. These formations are mainly composed of limestone, dolomitic limestone, and marls underlying generally Permo-Triassic formations composed of red clays and doleritic basalts, and covered in places by Quaternary terraces. Soils and their evolution depend essentially on the nature of the lithological substrates, which under the influence of environmental factors (climate, vegetation, exhibition, topography...) gives birth to different soil types. The climate is of a continental type. This site is located in mountainous areas and is marked by a great irregularity in the amounts of precipitation and a regression of vegetation cover due to human action.

The Oued Ikkour that is a tributary of the Oum Er Rbia River crosses a distance of $15 \mathrm{~km}$ before reaching the Zaouit Cheikh City. It is characterized by a steep slope of $\approx 10^{\circ}$ on average, an elongated shape and an index of compactness of 1.25. The Ikkour watershed presents rugged terrain with the highest elevation of $2209 \mathrm{~m}$. It is marked by a regression of forest cover due to agricultural extension, intensive pasture, and deforestation.

\section{Data}

The soil erosion assessment depends upon the regional characteristics of the area, namely climate, soil condition, land use/land cover, topography, and lithology. To prepare maps of these characteristics, the data used in this study are collected from various sources. The Landsat 8 OLI image with a resolution of $30 \mathrm{~m}$ was downloaded from Earth Explorer dated June 21, 2015. It has been properly used for the spectral index method. The digital elevation model (DEM) of $30 \mathrm{~m}$ resolution of the study area was downloaded from ASTER GDEM. It was used to generate topographic parameters (slope, hydrographic network). The geological map $(1: 500,000)$ of Rabat was used to digitize geological formations. The monthly and annual rainfall data from 1985 to 2014 were obtained from the Hydraulic Basin Agency of Oum Er Rbia and Tadla-Azilal Regional Directorate of Water and Forests. 


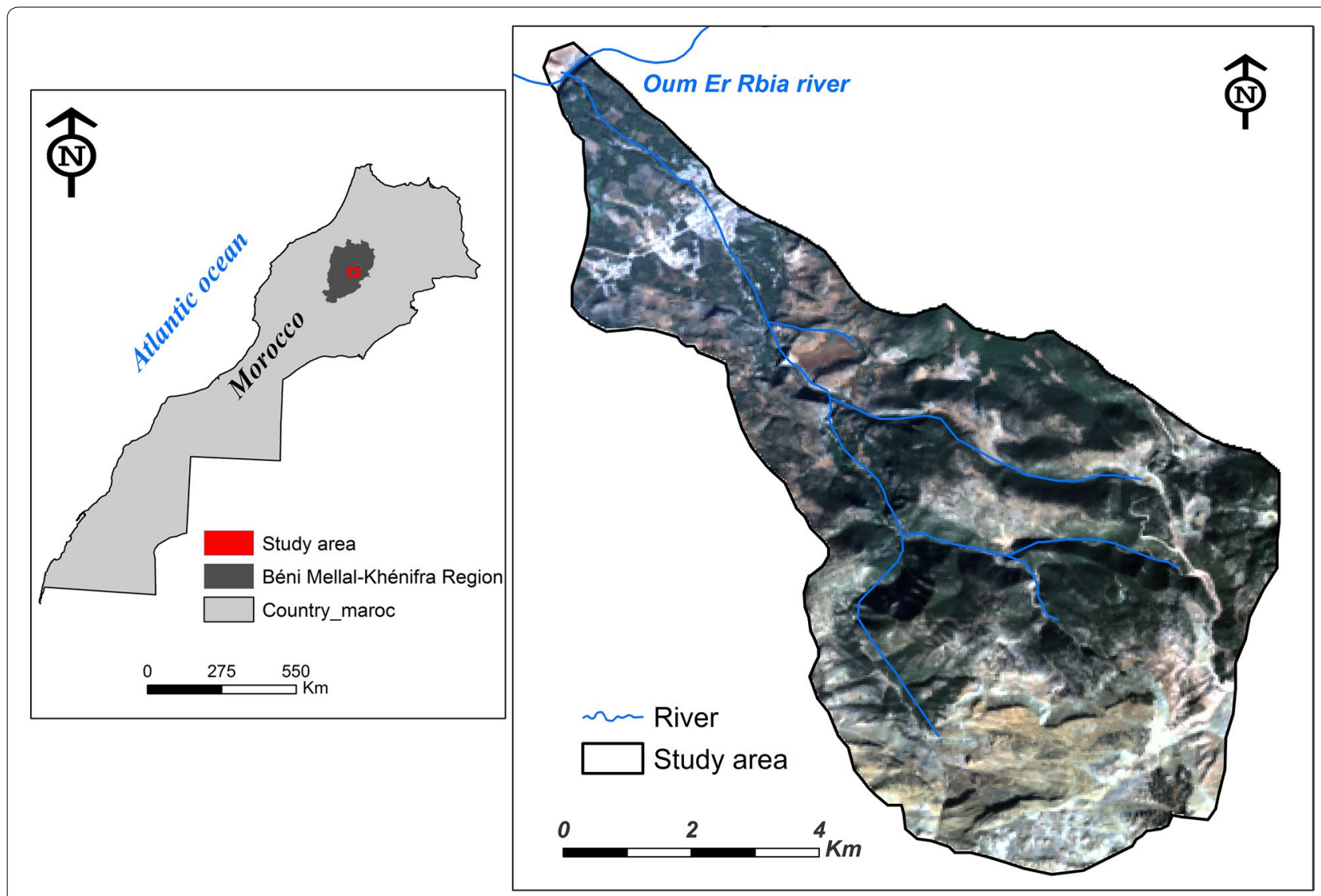

Fig. 1 Location of the study area

The topsoil samples were collected over 22 locations within the study watershed in order to determine soil texture and organic matter content. The soil texture was determined by the Robinson pipette method, and the soil EC was determined from the suspension prepared by adding $50 \mathrm{ml}$ de-ionized water to $10 \mathrm{~g}$ of sediment and shaking for $30 \mathrm{~min}$. The topographic parameters of the watershed and the thematic factor maps were extracted using ArcGIS 10.2 software.

\section{Methodology}

To assess water erosion of the study area, the erosion models, USLE and spectral indices, were applied. The first is a quantitative model which is considered to be a contemporary, simple, and widely used approach to soil erosion assessment. The second is a qualitative approach based on multi-indices. Each of these two approaches will be applied separately.

\section{Radiometric calibration and atmospheric corrections}

Radiometric calibration and atmospheric corrections are essential before any processing to reduce data uncertainty due to measuring instruments and atmospheric perturbations. Without these operations, the changes caused by artifacts relative to the sensor can be mistakenly attributed to changes in the land use and ground biophysical components. Consequently, errors can propagate in all subsequent steps taken during image processing, such as spectral index calculations, multitemporal analysis, climate change modeling, and target classification (Myneni and Asrar 1994; Bannari et al. 1999; Pahlevan et al. 2014; Vanhellemont and Ruddick 2014).

The Landsat 8 OLI image has been corrected for radiometric anomalies specific to the sensor, atmospheric effects, and geometric distortions and topographical features, to discern levels of soil degradation using various combinations in spectral indices. The Landsat-OLI sensor 8 acquires electromagnetic data and stores this information as a numerical value $(\mathrm{CN})$, with a range between 0 and 255. It is possible to convert these $\mathrm{CN}$ values to reflectance above the TOA atmosphere using the ENVI system. The first step is to convert the $\mathrm{CN}$ luminance values using the scene-specific gain and scene bias. The second step is to convert the radiance data to reflectance. The data used in this work are the USGS Landsat scenes 
provided with an ENVI-compliant "MTL" format metadata file.

To derive the coefficients of the atmospheric correction, there are several methods, which include Dark Object Subtraction (DOS) and the FLASH method (Spectral Fast-Spectral Analysis of Spectral Hypercubes). In this study, the DOS method was adopted due to its simplicity and satisfactory results, to eliminate the effects of atmospheric scattering by subtracting from each image band the value of the darkest pixel.

\section{USLE factor estimation and map derivation}

The USLE approach is compatible with GIS environment, which has been applied for soil risk erosion assessment in Ikkour after some modifications in the calculation of specific factors. Soil erosion was determined with the help of the USLE (Wischmeier and Smith 1978) but adapted in our study regarding the soil erosion risk in Morrocco (Heusch 1970; Ibrahimi 2006; Tribak 2000). Due to the similar climatic conditions, the model was considered satisfactory. Mathematically, the USLE incorporates five factors as indicated below:

$$
A=R \times K \times L S \times C \times P,
$$

where $A$ is the mean annual soil loss $\left(\right.$ ton $\mathrm{h}^{-1}$ year $^{-1}$ ), $R$ is the rainfall/runoff erosivity factor (MJ $\mathrm{mm} \mathrm{ha}^{-1} \mathrm{~h}^{-1} \mathrm{year}^{-1}$ ), $K$ is the soil erodibility factor (ton $\mathrm{h} \mathrm{MJ}^{-1} \mathrm{~mm}^{-1}$ ), LS is the slope length and steepness factor (dimensionless), $C$ is the cover factor (dimensionless), and $P$ is the support practice factor (dimensionless).

All USLE factors were derived as raster (grid with 30-30 m cell size) geographic layers after processing the original data. The factor layers were then overlaid and multiplied together, according to Eq. (1), for calculating the final risk map. The USLE model was simulated by remote sensing and GIS techniques as shown in Fig. 2.

\section{Rainfall erosivity (R) factor}

The $R$-factor measures the impact of rainfall on erosion in MJ mm ha ${ }^{-1} \mathrm{~h}^{-1}$ year $^{-1}$, and it is designed to represent the input that drives the sheet and rill erosion process through climatic factor. It is generally determined as a function of the volume, intensity, and duration of the rainfall. Its calculation, therefore, required detailed data regarding the quantity and intensity of the rainfall. Because of a lack of local rainfall data, we used the formula of Rango and Arnoldus (1987) adapted to Moroccan conditions (Eq. 2), due to the fact that these data are usually not measured in the studied area, we used an adapted formula to Moroccan conditions (Eq. 2) which estimated annual erosivity in relation to monthly and annual rainfall that of Rango and Arnoldus (1987). Rainfall data of 20 years (1985-2014) collected in five stations (El Ksiba, Koumch, Barrage Ahmed ELHansali, Aghbala, and Takbalt, located within or near the study area) by ABHOER were used for calculating the $R$-factor.

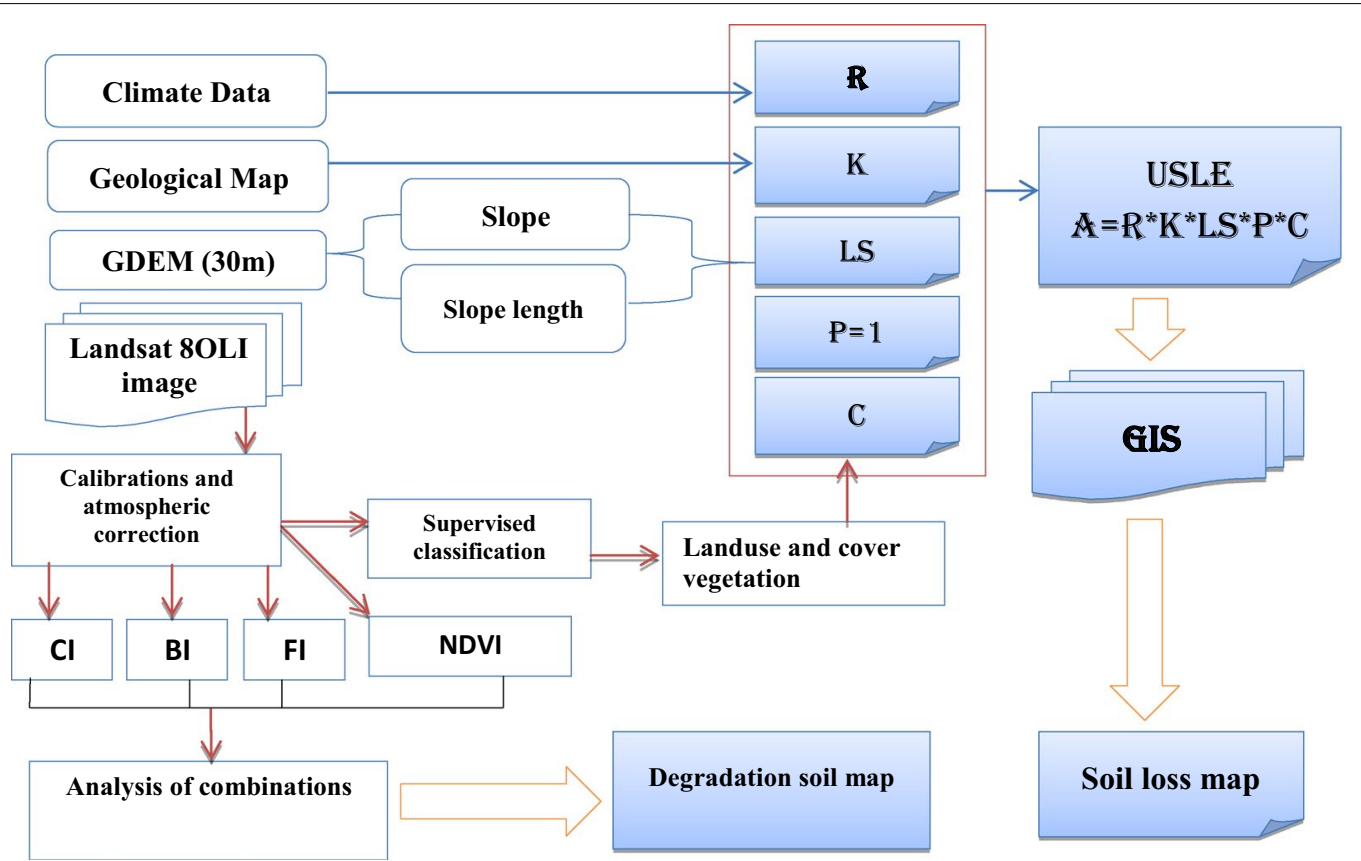

Fig. 2 Methodology flowchart 


$$
\log R=1.74 \times \log \sum\left(\frac{\mathrm{Pi}^{2}}{P}\right)+1.29,
$$

where $R$ is an erosivity factor (MJ mm ha ${ }^{-1} \mathrm{~h}^{-1}$ year $^{-1}$ ), $\mathrm{Pi}$ is the monthly rainfall $(\mathrm{mm})$, and $P$ is the annual rainfall (mm).

\section{Soil erodibility (K) factor}

The soil erodibility factor ( $K$-factor) represents both susceptibility of soil to erosion and the rate of runoff. The $K$-factor was computed by applying Eq. 3 developed by Wischmeier and Smith (1978).

Generally, the above values of the $K$-factor are applied at the scales of 1:50,000 and 1:10,000 when a soil map is available. However, due to unavailability of soil maps of the study area, the $K$-factor was derived from the geological map of Rabat at the scale 1:500,000, our soil analysis, and literature data. For the calculation of the $K$-factor, the formula (Eq. 3) suggested by Merzouk (1985) for the Moroccan conditions has been used in this study:

$K=311.63-4.48 \times(\mathrm{SG} \%+S \%)+613.4+6.45 \times \mathrm{EC}$,

where SG is the coarse sand content (in \%), $S$ is the sand content (in \%), and EC is the electrical conductivity.

The physical data for soil erodibility estimation were obtained from collecting soil samples covering the study area. The soil samples were analyzed for their texture (sand, silt, and clay contents) and electrical conductivity. The soil erodibility map was then prepared by assigning the $K$-factor values of respective soil types based on soil texture and electrical conductivity, on field expertise, and by comparison with studies conducted in Morocco for the calculation of the $K$-factor (Heusch 1970; Bollinne and Rosseau 1978; Diallo 2000; Nasl'haj 2009).

\section{Slope length (L) and slope steepness $(S)$ factor}

The LS-factor reflected the effect of topography on erosion, which is proportional to the length and steepness of the slope. The LS-factor map was produced in the ArcGIS environment from the DEM. The equation derived from Mitasova et al. (1996) was adopted (Eq. 4):

$$
\begin{array}{r}
\text { LS }=\left(\frac{\text { Flow accumulation } \times \text { Grid size }}{22.1}\right)^{0.4} \\
\quad \times\left(\frac{\sin (\text { slope }) \times 0.01745}{0.09}\right)^{1.4},
\end{array}
$$

where flow accumulation is a raster of accumulated flow to each cell and Grid size is the length of a cell side.

\section{Cover (C) factor}

The $C$-factor represents the effect of cropping and management practices on erosion rate. It has a close linkage to land use types and is a reduction factor in soil erosion vulnerability. It is defined as the ratio of soil loss from land cropped under specific conditions to the corresponding loss from clean-tilled, continuous fallow. The value of $C$ depends mainly on vegetation type, stage of growth, and cover percentage.

The $C$-factor remains the most important of the factors to reduce the risk of erosion. The plant cover and techniques of cultivation are the main factors depending directly on the human action that would accelerate or reduce erosion according to the case.

\section{Support practice $(P)$ factor}

The $P$-factor reflects the effect of contouring and tillage practices on soil erosion. The numerical value of $P$-factor is always between 0 and 1 according to the management of agricultural land. The $P$-factor value near to 0 indicates good conservation practice, and the value near to 1 indicates poor conservation practice.

\section{spectral index approach}

In arid lands, the soil by its changes in color and mineralogy and the vegetation by the variations in its structure and spatial distribution constituted indicators of change and degradation in natural environments (Smith et al. 1994). Within this context, the spectral indices based on soil reflectance, such as form index (FI), color index (CI), brightness index (BI), and normalized difference vegetation index (NDVI), to map soil erosion state in the Ikkour watershed.

\section{Coloration index}

Color is an important parameter used to characterize the state of the soil since the spectral signature of the soil depends on their composition and moisture content (Irons et al. 1989). The degraded soils that have low organic matter are clearer and brighter, and consequently they showed low CI values. The developed soils with limited degradation have high CI values. CI is developed by Escadafal et al. (1994), which corresponds to the normalized ratio of red and blue bands as expressed by Eq. 5 . The reflectance in this spectral region is greatly affected by the iron oxide absorption phenomenon (hematite and/ or goethite).

$$
\mathrm{CI}=\frac{\mathrm{OLI} 4-\mathrm{OLI} 2}{\mathrm{OLI} 2}
$$

\section{Form index}

The soils are characterized by their spectral reflectance degrees. This variability in reflectance is linked to the 
presence or absence of iron oxides and organic matter absorption bands. Thus, low reflectance levels are associated with low degraded soils (presence of iron oxide and absence of carbonate material). Therefore, FI is used to characterize the types of soils and their levels of degradation based on the formula (Eq. 6) developed by Escadafal et al. (1994). The shape of their spectral curves can be informative (Baumgardner et al. 1986; Haboudane 1999).

$$
\mathrm{FI}=\frac{2 \times \text { OLI } 4-\text { OLI } 3-\text { OLI2 }}{\text { OLI } 3-\text { OLI } 2}
$$

Several studies have used the form index to map the different levels of land degradation, especially in arid and semi-arid regions. Moreover, they informed that the integration of the SWIR bands into the FI equation has the potential to improve its ability to detect precisely land degradation classes (Bannari et al. 2008; Maimouni et al. 2012; Haboudane et al. 2002).

\section{Brightness index}

BI allows to distinguish the plant cover from the bare soil, and this is all the better if the soils are dry and clear (silica sand, limestone nodules, gypsiferous crust, etc.). Therefore, it is widely used as an indicator of the state of soil degradation. Thus, low BI is due to vegetation cover and high BI is due to barren land (soil/rock cover). This index is strongly correlated with iron oxide content in the sand dunes of a semi-arid environment (Levin et al. 2005). BI is determined by the following formula:

$$
\mathrm{BI}=\sqrt{R^{2}+G^{2}+B^{2}},
$$

where $R$ represents the red band, $G$ the green band, and NIR represents the near-infrared band.

\section{Normalized difference vegetation index}

The NDVI became one of the widely used indices for predicting surface soil characteristics and has been widely used in soil degradation assessment (Bannari et al. 2002; Maimouni et al. 2011; Bachaoui et al. 2014a, b). The soil loss rates increase when the vegetation cover decreases because the plant cover protects soil against erosion by reducing water runoff and by increasing water infiltration. NDVI is determined from the red and near-infrared (NIR) band values using the following formula (Eq. 8):

$$
\mathrm{NDVI}=\frac{\text { OLI5 }- \text { OLI } 4}{\text { OLI5 }+ \text { OLI4 }}
$$

\section{Results and discussion}

\section{USLE factor estimation and map derivation}

In this study, the USLE was integrated with GIS and remote sensing techniques to conduct cell-by-cell calculation of mean annual soil loss rate (ton ha ${ }^{-1}$ year $^{-1}$ ) and to identify and map soil erosion risk areas in the watershed of Ikkour maps of each USLE parameter derived from different data sources were developed and discussed as follows.

\section{Rainfall erosivity $(R)$ factor}

The $R$-factor measures the impact of rainfall on erosion in $\mathrm{MJ} \mathrm{mm} \mathrm{ha}{ }^{-1} \mathrm{~h}^{-1}$ year $^{-1}$. The $R$-factor values calculated for the four rain gauge stations have been used to produce the erosivity map of the study area (Fig. 3), by the application of the kriging interpolation method in ArcGIS 10.2 software. The $R$-factor values obtained for the study watershed area varied from $29.3 \mathrm{MJ} \mathrm{mm} \mathrm{ha}{ }^{-1} \mathrm{~h}^{-1}$ year $^{-1}$, in the northern areas, to $35.66 \mathrm{MJ} \mathrm{mm} \mathrm{ha}{ }^{-1} \mathrm{~h}^{-1}$ year $^{-1}$, in the southern areas, of the study watershed.

\section{Soil erodibility $(K)$ factor}

As a result, the $K$-factor erodibility of the watershed ranged between 0.05 and 0.41 (Fig. 4). It was higher in the upstream part of the watershed where the lands were escaped and barren, and in the downstream part of the watershed showing arable land without forest cover. Hence, these soils are highly affected by soil erosion.

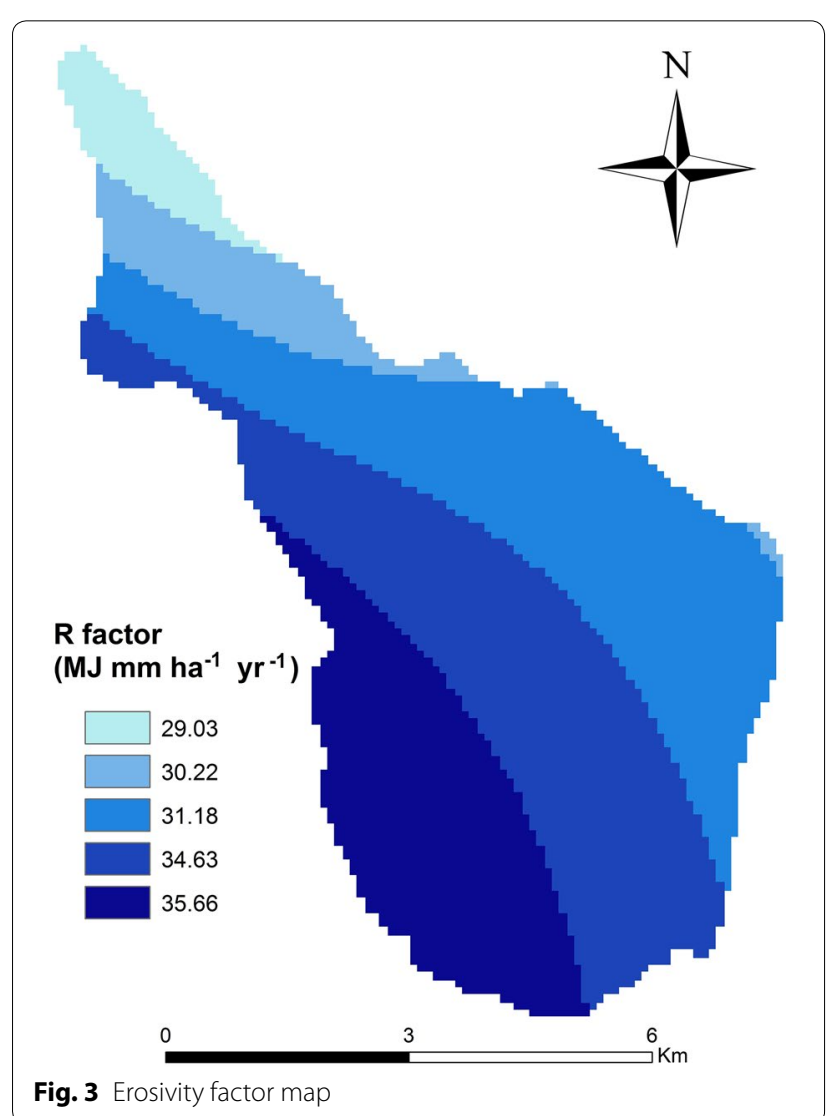




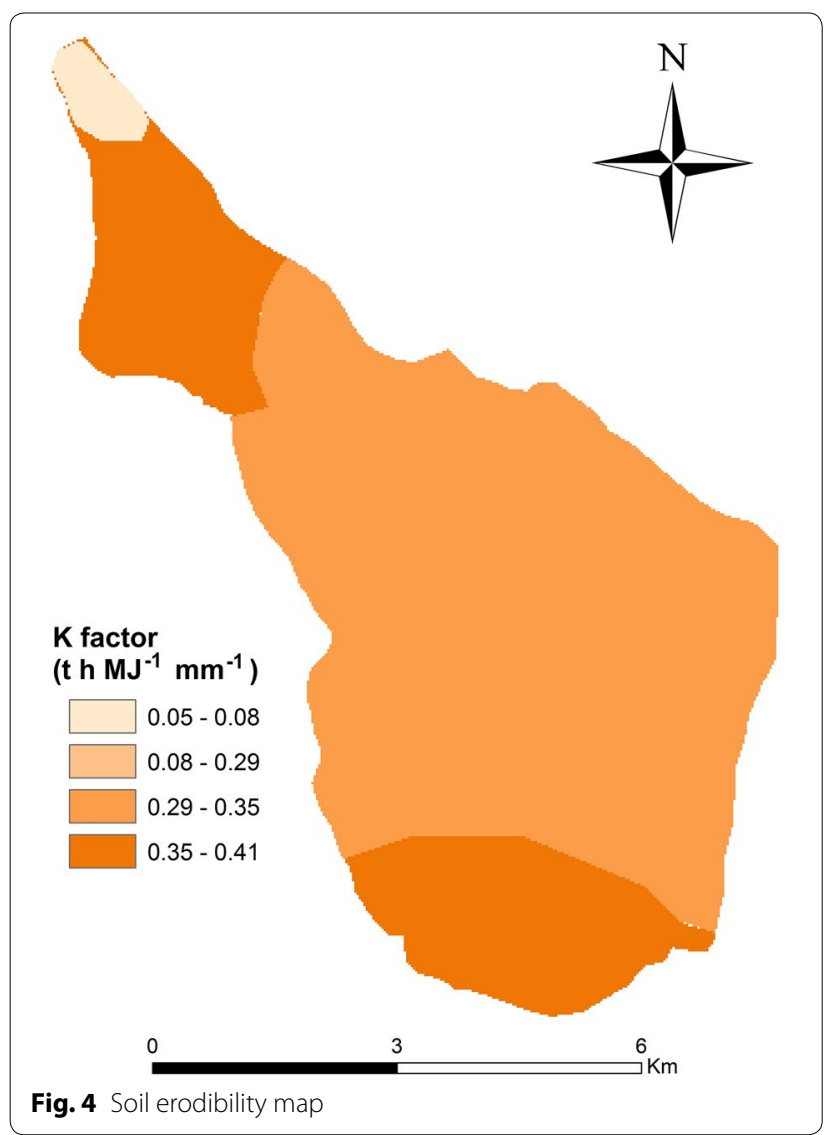

\section{Slope length ( $L$ ) and slope steepness $(S)$ factor}

From the analysis of the slope an LS-factor map (Fig. 5a, b), it is observed that the higher LS-factor values (10.23) in the study watershed have been encountered near the hydraulic network, the banks of which presented an abrupt change in slope, while the rest of the area showing gentle slope and predominantly grasslands remained very low (0.00).

\section{Cover (C) factor}

The $C$-factor map was generated using supervised classification maximum likelihood estimation of the Landsat 8 OLI image. The classified map, verified with field observations, categorized the study watershed into bare land, forest areas, arboricultural area, bushes, and built-up land (Fig. 6). With the help of the $C$-factor values available in literature (Issa et al. 2016), the $C$-factor values were assigned to each of these land use-land cover classes (Table 1 ) for the preparation of $C$-factor map.

The $C$-factor values in the watershed vary from 0 for the built-up areas to 0.1 for the arboricultural areas of the study watershed (Fig. 6, Table 1).

\section{Support practice $(P)$ factor}

In this study, the $P$-factor value assigned for the entire area was 1 , since there were no erosion control practices in the studied area. Agricultural practices in the study area are generally limited to fruit cultivation, particularly olive trees. The vegetable culture was located in the irrigated area. The ground surface is not prepared to limit soil erosion, except in limited areas where culture against the slope and earthworks were observed.

\section{Annual soil erosion estimation}

The erosion risk assessment in the Ikkour watershed was performed by overlaying the five USLE factor maps using ArcGIS spatial analyst. The soil erosion intensity map generated had the values categorized using the natural breaks (Jenks) classification method into four soil erosion classes, i.e., very weak, weak (2-5), moderate (5-15), and strong ( $>15)$. The average annual soil loss in the Ikkour watershed was 0.68 ton ha ${ }^{-1}$ year $^{-1}$. As can be seen from the soil erosion map (Fig. 7, Table 2), the highest values of estimated soil erosion potential that were around 70.66 ton/ha/year occurred in the main stream due to their high LS-factor values and an abrupt change in slope from 0 to $30.11 \%$. The estimation of soil erosion area coverage indicated that approximately 784 ha (about 14\%) of the study watershed showed strong water erosion and, consequently, high erosion risk. However, lower soil erosion occupied 4425 ha $(80 \%)$, coinciding with wooded areas. Previous studies conducted an assessment of soil erosion in Morocco, which showed different soil loss rates depending upon types of land and local conditions. At the level of the watershed of Oued Srou, a main tributary of Oued Oum Er-Rbia, ElbouqdaouiK et al. (2005) reported that the high, very high, and extremely high risk of erosion accounts for $43 \%$. According to these authors, the influence of precipitation on erosive phenomena is evident. Similarly, at the level of the Telata watershed Merzouk et al. (1996) showed that the highest losses were recorded in areas affected by mass movements with average losses of 524 ton ha ${ }^{-1}$ year $^{-1}$.

It was noticed that this analysis of soil erosion problems carried out by USLE approach provided important synthetic and systematic information on the nature, intensity, and spatial distribution of a phenomenon and therefore allowed identifying the most affected areas and the types of dominant erosion in the long term. This quantitative map can be an indispensable tool for the integrated management of soils.

\section{spectral index map derivation}

In addition to the USLE method, the analysis which has shed light on the importance of the spectral bands 


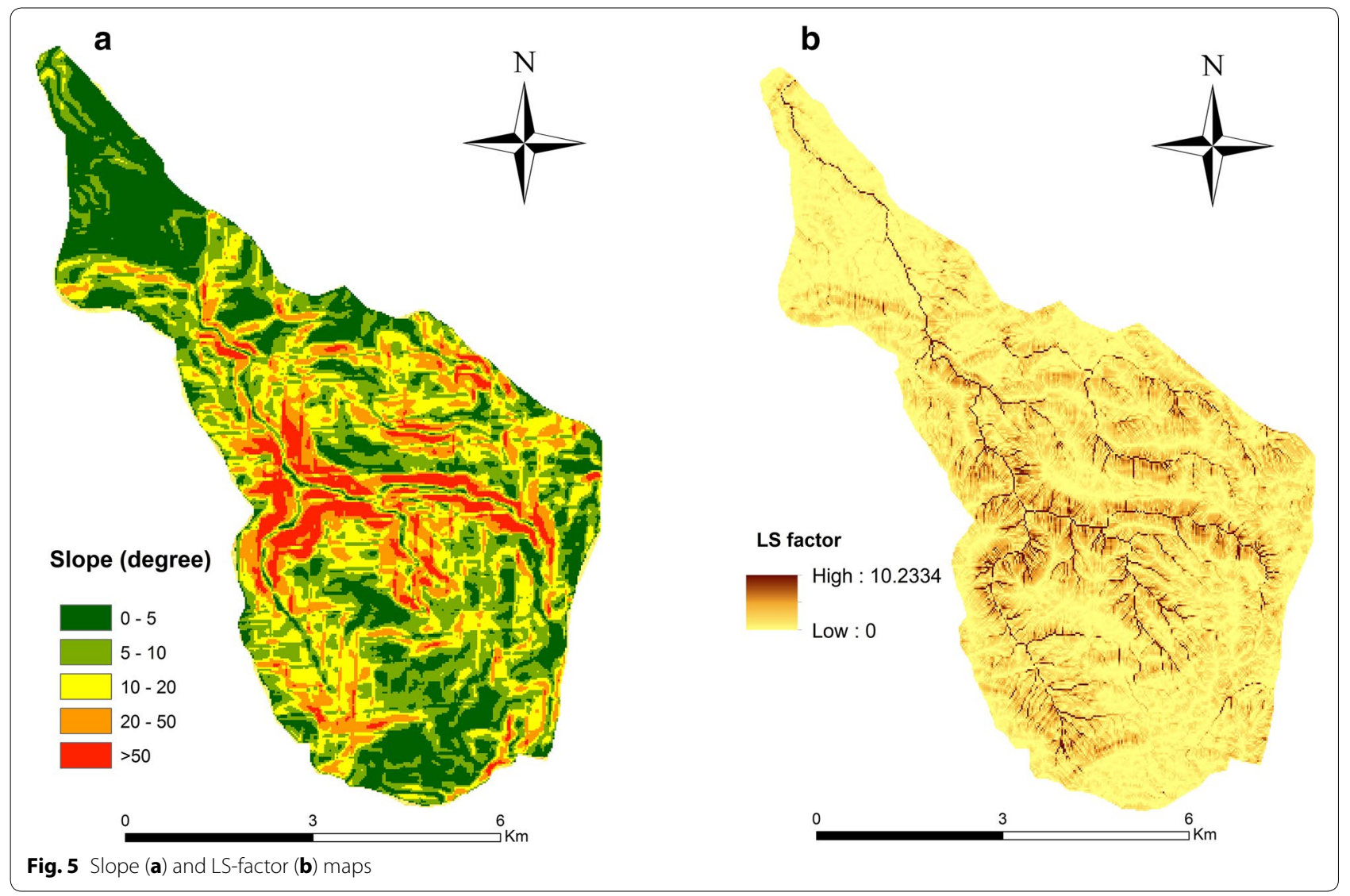

is more appropriate for the calculations of the spectral indices; in a second stage, more than 20 combinations of colored compositions have been studied in the RGB (Red-Green-Blue) system of image processing considering the various indices (FI, CI, BI, NDVI). Among all the combinations that were analyzed and compared, only one was retained because of its potential for characterizing soil degradation and soil occupation. This best combination considered the CI (4-2), NDVI (5-3), and FI (4-2-3) indices, respectively, in the RGB system, and allowed to generate the soil degradation map (Fig. 8).

The results from this approach showed a large variation of the indices describing the shape of the specter with the degree of degradation (Fig. 8). Therefore, they represent telling indicators of changes that affect the surface of the soil. Their application to the data from the satellite image has helped map the state of the environment in general and the level of deterioration of the soils in particular. In effect, the combined use of these variables allowed better discrimination of the different states of soil, and the surface conditions of the soil occupation units were then identified by distinctive colors. The analysis of the results allowed us to identify that strong and moderate degrees are fairly well defined (Table 3).
The second approach adopted in this research did not intend to estimate the amount of soil loss, but to provide erosion risk map for the analysis of planning and environment protection.

The comparison of the results obtained by the two approaches shows an important correlation that the strongly degraded land obtained by the spectral index approach has a high rate of erosion, whereas the weakly degraded soil presents a low rate of erosion. This is quite normal. In effect, in the high part of the watershed, the soils are highly degraded that the parent rock outcrops on the surface, and the erosion is therefore highly corresponding to class over than 15 ton ha ${ }^{-1}$ year $^{-1}$. The soils that are weakly degraded, are located in the middle and downstream of the watershed. These soils are deep and fertile, and promote therefore a protected land.

From this study, it seems clear that the expansion of agricultural lands into the forested lands and changes in farming practices in the studied watershed and throughout the Béni-Mellal region (Barakat et al. 2017) have a negative effect on soil quality and, thereby, river water quality. The land users and farmers need to be made aware of the need to conserve this resource through sustainable soil usage. 


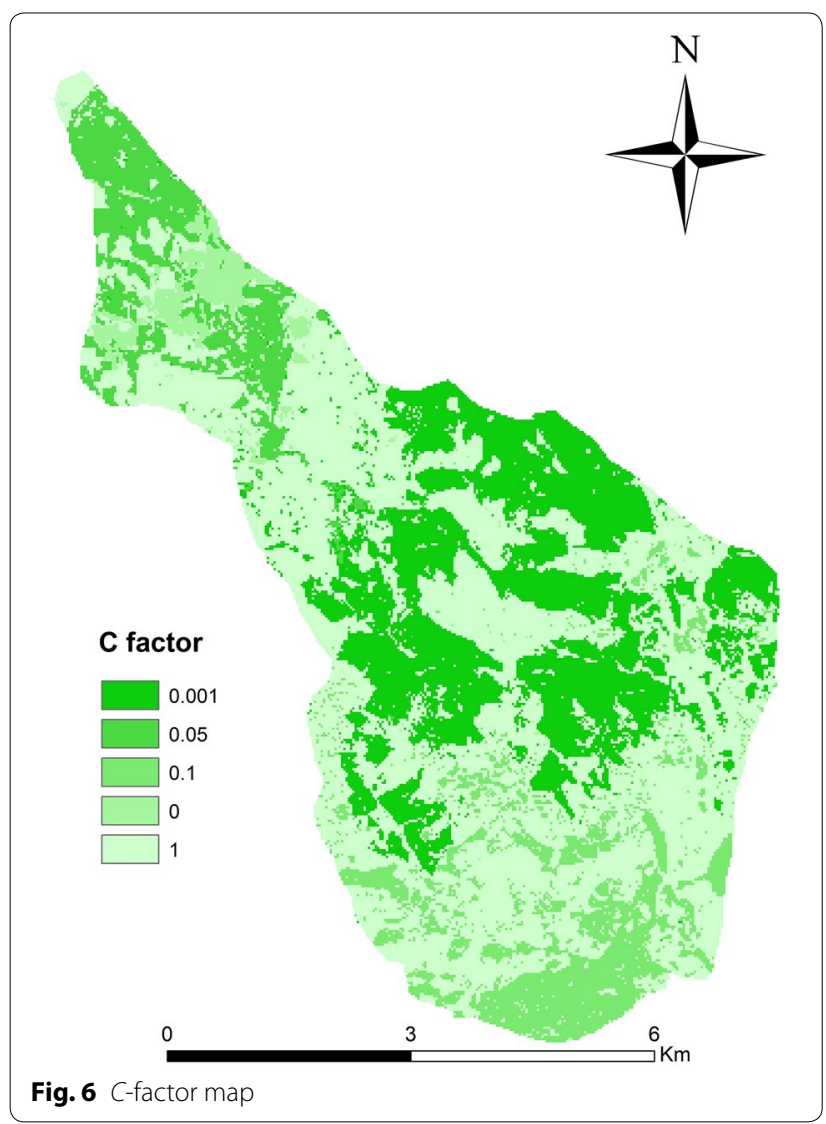

Table 1 Land use-land cover classes and the respective C-factor values

\begin{tabular}{llll}
\hline Classes & \multicolumn{2}{l}{ Area } & C-factor \\
\cline { 2 - 3 } & ha & \% & \\
\hline Bare land & 2825.15 & 52 & 1 \\
Forest land & 1428.01 & 26 & 0.001 \\
Arboricultural area & 430.01 & 8 & 0.1 \\
Bushes & 572.16 & 11 & 0.05 \\
Built-up land & 160 & 3 & 0 \\
\hline
\end{tabular}

\section{Conclusion}

The watershed of Ikkour in the Middle Atlas (Morocco) is known to have significant soil erosion problems. This study has been carried out to estimate soil erosion in the Ikkour watershed using USLE and spectral index approaches to the GIS environment.

The quantitative approach by the USLE model has shown that the average annual loss in the evaluated watershed is 0.68 ton $\mathrm{ha}^{-1}$ year $^{-1}$. This soil loss quantity would be favored by the erosion factors controlling soil loss, such as steep slopes (nearly $40 \%$ of the total surface

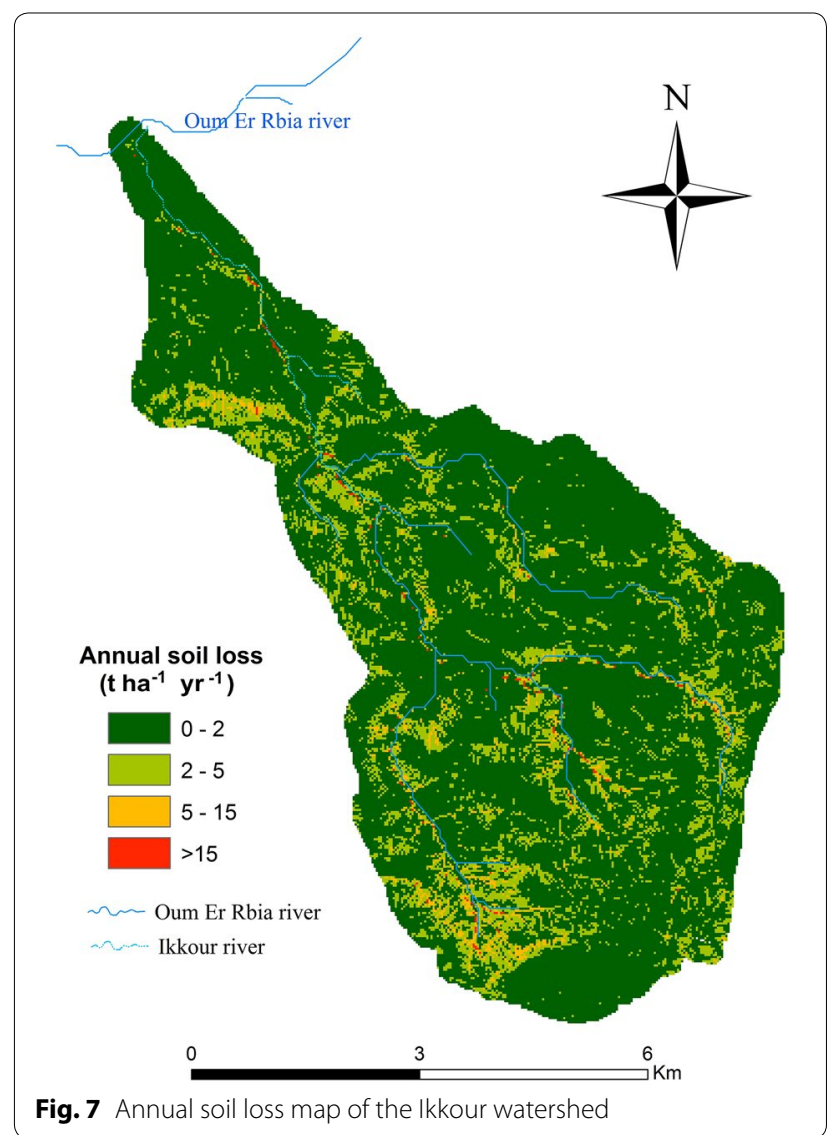

area of the watershed showed a slope value more than $20 \%$ ), moderately erodible lands (57\% of lands showed a $K$-factor between 0.45 and 0.5 ), and degraded plant cover.

The spectral index (CI, NDVI, FI) approach has allowed to produce the soil degradation map. It showed that the strongly degraded lands are located in the upstream part of the studied watershed. By contrast, the weakly degraded lands are situated in the downstream part of the watershed. They are characterized by their fertility and wealth and are protected by the arboriculture.

The combined use of the two approaches, quantitatively by USLE and qualitatively by the spectral index method, shows a certain agreement toward the sites most vulnerable to water erosion. The two approaches complement each other and each brings its share of information: that of spectral indices showed different levels of soil degradation, whereas the USLE method provides a quantitative argument aimed to illustrate the sensitivity of the study area against water erosion.

Overall, we have suggested that the combination of two approaches, USLE and spectral indices, could be an indispensable tool for integrated soil management, especially with the perspective to evaluate and map the soil erosion risk. It could also serve as a tool to help in 
Table 2 Classification of soil loss rate in the Ikkour watershed

\begin{tabular}{|c|c|c|c|}
\hline Soil loss (ton ha ${ }^{-1}$ year $^{-1}$ ) & Intensity & Area (ha) & $\begin{array}{l}\text { Area } \\
\text { (\%) }\end{array}$ \\
\hline $0-2$ & Very weak & 4425 & 80 \\
\hline $2-5$ & Weak & 24 & 0.44 \\
\hline $5-15$ & Moderate & 784 & 14.65 \\
\hline$>15$ & Strong & 293 & 6 \\
\hline
\end{tabular}

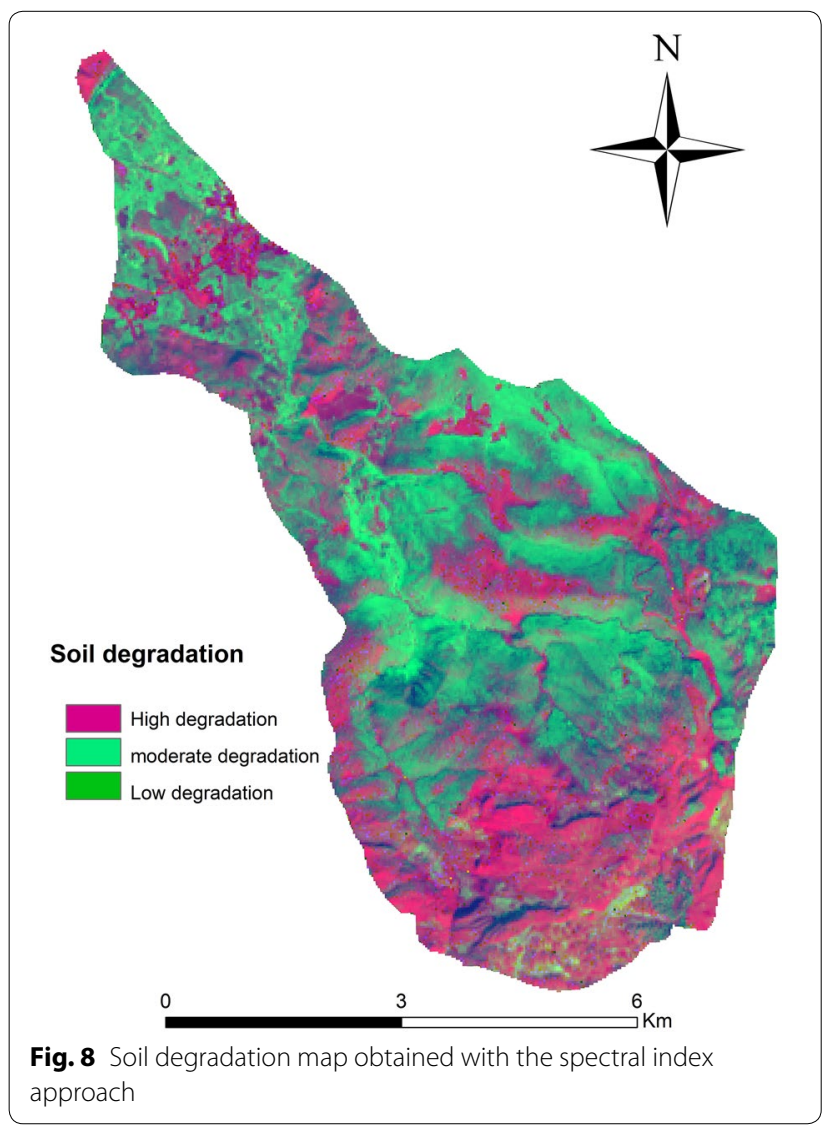

Table 3 Classification of soil degradation in the Ikkour watershed

\begin{tabular}{llll}
\hline Soil degradation & $\begin{array}{l}\text { Soil loss (ton } \\
\text { ha }^{-\mathbf{1}} \text { year }^{\mathbf{- 1}} \text { ) }\end{array}$ & Area (ha) & Area (\%) \\
\hline Low & $2-5$ & 1245 & 23 \\
Moderate & $5-15$ & 2285 & 42 \\
High & $>15$ & 1881 & 35 \\
\hline
\end{tabular}

establishing effective culture and governance and in supporting practices management reducing the soil erosion rate. The results obtained from this study are very promising and can assist policy makers to develop soil erosion management strategies.

\section{Abbreviations}

USLE: Universal soil loss equation; GIS: Geographical Information Systems; FI: form index; Cl: coloration index; BI: brightness index; NDVI: normalized difference vegetation index; DEM: digital elevation model.

\section{Authors' contributions}

All authors contributed to study design and data and data interpretation. Aafaf El Jazouli and Ahmed Barakat contributed to study design, data collection and interpretation, manuscript preparation, and literature search. All authors read and approved the final manuscript.

\section{Author details}

${ }^{1}$ Georesources and Environment Laboratory, Faculty of Sciences and Techniques, Sultan My Slimane University, Béni-Mellal, Morocco. ${ }^{2}$ Department of Geology, Faculty of Sciences-Ben Msik, Hassan II University, Casablanca, Morocco. ${ }^{3}$ Regional Directorate of Water and Forests (DREFLCD-TA), Béni-Mellal, Morocco.

\section{Acknowledgements}

Not available.

\section{Competing interests}

The authors declare that they have no competing interests.

\section{Availability of data and materials}

Not available.

\section{Funding}

Not available.

\section{Publisher's Note}

Springer Nature remains neutral with regard to jurisdictional claims in published maps and institutional affiliations.

Received: 28 January 2017 Accepted: 8 November 2017

Published online: 15 November 2017

\section{References}

Alexakis DD, Hadjimitsis DG, Agapiou A (2013) Integrated use of remote sensing, GIS and precipitation data for the assessment of soil erosion rate in the catchment area of "Yialias" in Cyprus. Atmos Res 131:108-124 Bachaoui B, Bachaoui EM, Maimouni S, Lhissou R, El Harti A, El Ghmari A (2014a) The use of spectral and geomorphometric data for water erosion mapping in El Ksiba Region in the central High Atlas Mountains of Morocco. Appl Geomat 6:159-169

Bachaoui M, Bachaoui B, Lhissou R, El Harti A, El Ghmari A (2014b) Modeling and mapping water erosion risks in the High Atlas of Morocco: the Atlas of Beni Mellal as a case in point. J Remote Sens GIS 2(1):2052-5583

Bannari A, Teillet PM, Richardson G (1999) Nécessité de l'étalonnage radiométrique et standardisation des données de télédétection. Journal Canadien de Télédétection 25:45-59 
Bannari A, Asalhi H, Teillet P (2002) Transformed difference vegetation index (TDVI) for vegetation cover mapping. In: IEEE International geoscience and remote sensing symposium, pp 3053-3055

Bannari A, El-Harti A, Haboudane D, Bachaoui M, El-Ghmari A (2008) Intégration des variables spectrales et géomorphométriques dans un SIG pour la cartographie des zones exposées à l'érosion. Rev Télédét 7(1-2):3-4

Barakat A, El Baghdadi M, Rais J, Aghezzaf B, Slassi M (2016) Assessment of spatial and seasonal water quality variation of Oum Er Rbia River (Morocco) using multivariate statistical techniques. Int Soil Water Conserv Res 4(4):284-292

Barakat A, Ennaji W, El Jazouli A, Amediaz R, Touhami F (2017) Multivariate analysis and GISbased soil suitability diagnosis for sustainable intensive agriculture in Beni-Moussa irrigated subperimeter (Tadla plain, Morocco). Model Earth Syst Environ 3(1):3. http://doi.org/10.1007/ s40808-017-0272-5

Baumgardner MF, Silva LF, Biehl LL, Stoner ER (1986) Reflectance properties of soils. Adv Agron 38:1-44

Ben-Ali D (2000) Les sources documentaire et statistique se rapportant aux domaines des ressources naturelles et l'environnement au Maroc. In: Femisenetwork, Ed. Comptabilité de l'environnement dans le cadre d'une matrice des comptes sociaux: Le cas du Maroc; Euro-Mediterranean Forum Economic Institute

Benzer N (2010) Using the geographical information system and remote sensing techniques for soil erosion assessment. Pol J Environ Stud 19(5):881-886

Biswas S (2012) Estimation of soil erosion using remote sensing and GIS and prioritization of catchments. Int J Emerg Technol Adv Eng 2(7):124

Bollinne A, Rosseau P (1978) L'erodibilite des sols de Moyenne et Haute Belgique. Utilisation d'une methode de calcul du facteur $\mathrm{K}$ de l'équation universelle de perte de sol. Bull Soc Géogr Liège 14(4):127-140

Chatterjee S, Krishna AP, Sharma AP (2014) Geospatial assessment of soil erosion vulnerability at watershed level in some sections of the Upper Subarnarekha river basin, Jharkhand. India Environ Earth Sci 71 (1):357-374

Dabral PP, Baithuri N, Pandey A (2008) Soil erosion assessment in a hilly catchment of North eastern India using USLE, GIS and remote sensing. Water Res Manag 22(12):1783-1798

De Ploey J, Kirkby MJ, Ahnert F (1991) Hillslope erosion by rainstorms-a magnitude-frequency analysis. Earth Surf Process Landf 16(5):399-409

Demirci A, Karaburun A (2012) Estimation of soil erosion using RUSLE in a GIS framework: a case study in the Buyukcekmece Lake watershed, Northwest Turkey. Environ Earth Sci 66:903-913

Diallo A (2000) Intégration du modèle USLE dans un SIG pour la cartographie de l'érosion hydrique dans le bassin versant de Beni Boufrah (Rif central). Mémoire de troisième cycle, ENFI

ElbouqdaouiK EzzineH, BadrahouM RouchdiM, Zahraoui M, Ozer A (2005) Approche méthodologique par télédétection et SIG de l'évaluation du risque potentiel d'érosion hydrique dans le bassin versant de l'Oued Srou (Moyen Atlas, Maroc). Geo Eco Trop 29:25-36

Escadafal R, Belghit A, Ben-Moussa A (1994) Indices spectraux pour la télédétection de la dégradation des milieux naturels en Tunisie aride. In: Guyot, G. réd. Actes du $6^{\text {ème }}$ Symposium International sur les mesures physiques et signatures en télédétection, Val d'Isère (France)

FAO (1990) Conservation des ressources naturelles en zones arides. Cahier FAO: Conserv Des Sols 50:62

Fullen MA (2003) Soil erosion and conservation in northern Europe. Prog Phys Geogr 27:331-358

Ganasri B, Ramesh H (2015) Assessment of soil erosion by RUSLE model using remote sensing and GIS - a case study of Nethravathi Basin. Geosci Front 7(6):953-961

Haboudane D (1999) Intégration des données spectrales et geomorphometriques pour la caracterisation de la dégradation des sols et l'identification des zones susceptibilité à l'érosion hydrique. Département de Géographie et Télédétection, Université de Sherbrooke, Sherbrooke, p 174

Haboudane D, Bonn F, Royer A, Sommer S, Mehl W (2002) Land degradation and erosion risk mapping by fusion of spectrally-based information and digital geomorphometric attributes. Int J Remote Sens 23:3795-3820

Haboudane D, Bonn F, Royer A (2007) Evaluation and predictability of terrain susceptibility to hillslope erosion at the regional scale using DEM-derived indices and remotely sensed information. Rev Télédétect 7:373-391

Heusch B (1970) Lérosion du Pré Rif occidental: une étude quantitative de l'érosion hydrique. Ann Rech For Maroc 12:9-176
Hill J, Mehl W, Altherr M (1994) Land degradation and soil erosion mapping in a Mediterranean ecosystem. Imaging spectrometry - a tool for environmental observations. Springer, Berlin, pp 237-260

Ibrahimi S (2006) Quantification de l'érosion hydrique des sols cultivés et non cultivés par deux radioéléments le $137 \mathrm{Cs}$ et le $210 \mathrm{~Pb}$ au niveau des bassins versants El Hachef et Raouz (Région de Tanger-Tétouan, Nord-Ouest Marocain). Thèse de Doctorat. Faculté des Sciences et Technique de Tanger. Université Abdelmalek Essaâdi

Irons JR, Weismiller RA, Petersen GW (1989) Soil Relectance. In: Asrar G (ed) Theory and applications of optical remote sensing. Wiley, New York, pp 66-106

Issa LK, Lech-Hab KBH, Raissouni A, El Arrim A (2016) Cartographie quantitative du risque d'erosion des sols par approche SIG/USLE au niveau du bassin versant Kalaya (Maroc Nord Occidental). J Mater Environ Sci 7(8):2778-2795

Joftic L, Milliman J, Sestini G (1992) Climate change and the Mediterranean. UNEP-E. Arnold Pub, New York, p 20

Kourgialas NN, Koubouris GC, Karatzas GP, Metzidakis I (2016) Assessing water erosion in Mediterranean tree crops using GIS techniques and field measurements: the effect of climate change. Nat Hazards 83(1):65-81

Kumar A, Devi M, Deshmukh B (2014) Integrated remote sensing and geographic information system based RUSLE modelling for estimation of soil loss in western Himalaya, India. Water Res Manag 28:3307-3317

Lal R (2001) Soil degradation by erosion. Land Degrad Dev 12(6):519-539

Levin N, Ben-Dor E, Singer A (2005) A digital camera as a tool to measure colour indices and related properties of sandy soils in semi-arid environments. Int J Remote Sens 26(24):5475-5492

MAEF (Ministère de l'agriculture, du développement rural et des eaux et forêts) (2001) Programme d'action national de lutte contre la désertification. Royaume du Maroc, Rabat, p 93

Maimouni S, Bannari A, El-Harti A, El-Ghmari A (2011) Potentiels et limites des indices spectraux pour caractériser la dégradation des sols en milieu semi-aride. Canad J Remote Sens 37:285-301

Maimouni S, El-Harti A, Bannari A, Bachaoui E-M (2012) Water erosion risk mapping using derived parameters from digital elevation model and remotely sensed data. Geospatial Inform Sci 15:157-169

Merritt WS, Letcher RA, Jakeman AJ (2003) A review of erosion and sediment transport models. Environ Modell Soft 18:761-799

Merzouk A (1985) Relative erodibility of nine selected Moroccan soils related to their physical and chemical and mineralogical properties. Ph-D Thesis, University of Minnesota, USA

Merzouk A, Fenjiro I, Laouina A (1996) Cartographie de l'évolution des formes d'érosion dans le Rif occidental (Maroc): étude multidate utilisant un SIG bassin versant. Bulletin-Réseau Erosion 16:444-456

Meusburger K, Bänninger D, Alewell C (2010) Estimating vegetation parameter for soil erosion assessment in an alpine catchment by means of QuickBird imagery. Int J Appl Earth Observ Geoinformat 12:201-207

Mitasova H, Hofierka J, Zlocha M, Iverson LR (1996) Modelling topographic potential for erosion and deposition using GIS. Int J Geogr Inform Syst 10:629-641

Myneni RB, Asrar G (1994) Atmospheric effects and spectral vegetation indices. Remote Sens Environ 17:390-402

Napoli M, Cecchi S, Orlandini S, Mugnai G, Zanchi CA (2016) Simulation of field-measured soil loss in Mediterranean hilly areas (Chianti, Italy) with RUSLE. Catena 145:246-256

Nasl'haj Y (2009) Evaluation de l"érosion des sols et proposition d'aménagement du bassin versant à l'amont du barrage Hassan II, Haute Moulouya, Maroc. Mémoire de troisième cycle, IAV, Rabat. 77 p

Pahlevan N, Lee Z, Wei J, Schaaf CB, Schott JR, Berk A (2014) On-orbit radiometric characterization of OLI (Landsat-8) for applications in aquatic remote sensing. Remote Sens Environ 154:272-284

Pandey A, Chowdary VM, Mal BC (2007) Identification of critical erosion prone areas in the small agricultural watershed using USLE, GIS and remote sensing. Water Res Manag 21(4):729-746

Perović V, Životić L, Kadović R, Đorđević A, Jaramaz D, Mrvić V, Todorović M (2013) Spatial modelling of soil erosion potential in a mountainous watershed of South-eastern Serbia. Environ Earth Sci 68:115-128

Rahman MR, Shi ZH, Chongfa C (2009) Soil erosion hazard evaluation-an integrated use of remote sensing, GIS and statistical approaches with biophysical parameters towards management strategies. Ecol Model 220:1724-1734 
Rango A, Arnoldus H (1987) Aménagement des bassins versants Cahiers techniques de la FAO, pp 1-11

Rawat KS, Mishra AK, Bhattacharyya R (2016) Soil erosion risk assessment and spatial mapping using LANDSAT-7 ETM+, RUSLE, and GIS-a case study. Ar J Geosci 9(4):1-22

Renard KG, Foster GR, Weesies G, McCool D, Yoder D (1997) Predicting soil erosion by water: a guide to conservation planning with the Revised Universal Soil Loss Equation (RUSLE), vol 703. US Government Printing Office, Washington

Sheikh AH, Palria S, Alam A (2011) Integration of GIS and universal soil loss equation (USLE) for soil loss estimation in a Himalayan watershed. Recent Res Sci Technol 3(3):51-57

Smith MO, Adams JB, Sabol DE (1994) Mapping sparse vegetation canopies. Imaging spectrometry - a tool for environmental observations. Springer, Berlin, pp 221-235

Tribak A (2000) L'érosion hydrique en moyenne montagne du pré-rif oriental (Maroc). Etude des agents et des processus d'érosion dans une zone de marnes tertiaires. Thèse de doctorat. Univ. Chouaib Doukkali, F.L.S.H. 163p
Vanhellemont Q, Ruddick K (2014) Turbid wakes associated with offshore wind turbines observed with Landsat 8. Remote Sens Environ 145:105-115

Wischmeier WH, Smith DD (1978) Predicting rainfall erosion losses—a guide to conservation planning. Agriculture handbook 537. U.S. Department of Agriculture, Washington

Yadav RP, Sidhu GS (2010) Assessment of soil erosion in Himachal Pradesh. J Indian Soc Soil Sci 58(2):212-220

Yesou H, Besnus Y, Rolet J (1993) Extraction of spectral information from Landsat TM data and merger with SPOT panchromatic imagery - a contribution to the study of geological structures. ISPRS J Photogr Remote Sens 48:23-36

Zhang K, Shu A, Xu X, Yang Q, Yu B (2008) Soil erodibility and its estimation for agricultural soils in China. J Arid Envir 72:1002-1011

\section{Submit your manuscript to a SpringerOpen ${ }^{\odot}$ journal and benefit from:}

- Convenient online submission

- Rigorous peer review

- Open access: articles freely available online

- High visibility within the field

- Retaining the copyright to your article

Submit your next manuscript at $\boldsymbol{\nabla}$ springeropen.com 